\title{
Allergenic potential of cosmetic ingredients
}

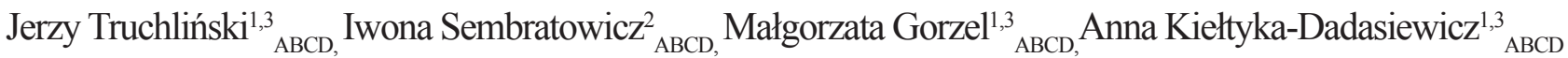 \\ ${ }^{1}$ Vincent Pol University in Lublin \\ ${ }^{2}$ University of Life Sciences in Lublin \\ ${ }^{3}$ Research \& Science Innovation Centre in Lublin
}

\begin{abstract}
The present study discusses basic issues of cosmetological allergology, the essence of allergy and its mechanism. Allergenic and irritating effects of fragrance substances, preservatives, dyes, artificial nails and other cosmetic compounds causing allergic symptoms have been demonstrated. Moreover, legal aspects regarding safety of cosmetics have been analysed.
\end{abstract}

Key words: allergenicity of cosmetics, fragrance substances, preservatives, dyes, artificial nails, other ingredients of cosmetics

\section{Introduction}

The development of modern civilisation results in increased numbers of allergic reactions in humans. The issue also regards cosmetics as a source of allergies, poisonings and infections $[1,2,3,4]$. Cosmetics are substances or mixtures designed for external contact with the human body, i.e. the skin, lips, nails, external genital organs, teeth and oral mucosa. They contain numerous substances, which have beneficial effects but can also be dangerous for health $[5,6,7,8]$. The affected individuals are not only those using cosmetics but also those exposed to cosmetic ingredients due to their profession $[9,10,11]$. Harmful effects of some chemical compounds are difficult to determine, as their negative action can emerge even after 10-20 years. It should be stressed that if our organism is not allergic to a particular ingredient, the precondition for safety is proper quality of cosmetic ingredients. Moreover, storage is essential, thus users can also affect the safety of cosmetics. The susceptibility to allergy can be inherited yet increasing environmental pollution and chemisation of life contribute to its development. Scentless substances can be dangerous as well, although individuals may not be aware of contact with them. All those substances result in growing numbers of allergies in humans. It is increasingly difficult to detect allergenic substances, as anything can cause an allergy and the way to prevent it is to limit contact with the irritant $[1,4,9,10]$. The paper discusses basic issues of cosmetological allergology, the essence of allergy and its mechanism. Allergenic and irritating effects of fragran- ce substances, preservatives, dyes, artificial nails and other compounds contained in cosmetics and causing allergic symptoms have been determined. Moreover, legal aspects regarding safety of cosmetics have been analysed.

\section{The essence of allergy and its mechanism}

An allergy is an improper reaction of the body in which certain environmental substances (allergens) are recognized as foreign and harmful. The immune system mobilizes the immune cells and starts fighting with the factors that invaded the body, which are usually harmless for healthy organisms $[12,13]$. The reaction leads to the development of systemic and organ disease symptoms [14].

\section{Cosmetic-induced allergic reactions}

Allergic processes can affect humans and animals; their symptoms and consequences depend on the mechanism of immune response. Four major types of immune reactions are distinguished:

anaphylactic-atopic,

cytolytic and cytotoxic,

immune complex-mediated (Arthus),

delayed [15].

The cosmetic intolerance syndrome depends on various exogenous factors and its incidence in the population is increasingly high [1]. The skin is the biggest organ of the human body, constituting $20 \%$ of total weight; its surface in an adult of average built and height of about $175 \mathrm{~cm}$ is $1.7 \mathrm{~m} 2$. The skin 
has numerous functions essential for maintaining health and life; it separates the body interior from the external world. The natural coat regulates temperature maintaining it at $36.6^{\circ} \mathrm{C}$. It protects against the external pressure and all external factors, which could irritate and damage the body, such as chemical substances, foreign bodies, high and low temperature, excessive sun radiation. Thanks to its ability to eliminate water by evaporation, the skin provides cooling necessary for survival whereas the layer of numerous adipose cells protects against cold [16]. Chemical compounds can permeate through the skin into the body via intercellular spaces, epithelial cells or sebaceous glands and hair follicles [9]. Deteriorated protective efficiency of the skin due to enhanced effects of the external environment or impaired general immunity are the main causes of environmental skin diseases, including allergies [17].

Cosmetics mainly cause contact allergies (Table

Table 1. Allergic skin reactions induced by cosmetics skin but rather on the regions of the neck, forehead or even face [18]. In cases of irritation-induced eczema, skin lesions located at the site of cosmetic application do not disseminate and their severity depends on the concentration of irritating substances and time of contact with the skin [19]. A relevant factor affecting the development of allergy is the condition of skin. In many cases, the same cosmetic applied to the irritated skin causes allergy while used on the healthy skin does not, e.g. aftershave. Moreover, hypersensitivity is affected by age and sex. Women and young people have more sensitive skin than men and the elderly [20].

Specific allergic reactions develop in genetically predisposed individuals; skin lesions can disseminate and their severity depends on the allergen concentration [1]. Possible development of allergic reactions is determined by the frequency of cosmetic application. Regular use of cosmetics containing a potential, even weak allergen, often leads to allergic reactions [21].

\begin{tabular}{|l|l|}
\hline \multicolumn{1}{|c|}{ Type of allergy } & \multicolumn{1}{c|}{ Characteristic } \\
\hline Irritation syndrome & $\begin{array}{l}\text { The most common form of dermatitis associated with cosmetics: } \\
\text { Objective: local inflammation - skin redness and damage, acne lesions connected with keratini- } \\
\text { sation of hair follicles } \\
\text { Subjective - increased pruritus and feeling of discomfort, can occur without any visible clinical } \\
\text { changes [1] }\end{array}$ \\
\hline Contact urticaria & $\begin{array}{l}\text { Allergic - in allergic individuals, particularly with concomitant atopy. It manifests with redness } \\
\text { and urticarial eruptions developing in a short time (15-60 min.) after cosmetic use. Lesions do } \\
\text { not leave scars and can be accompanied by conjunctivitis, inflammation of the nasal mucosa, } \\
\text { asthma [12]. } \\
\text { Non-immune-modulated - only skin lesions, no other symptoms; caused by benzoic and cinna- } \\
\text { mic acid [1]. }\end{array}$ \\
\hline Contact dermatitis & $\begin{array}{l}\text { The effector phase of contact eczema is characterised by the erythema, papules and blebs. In } \\
\text { chronic conditions, lichenisation (skin roughness and dryness) is also observed. Eczema does } \\
\text { not depend on the irritating agent dose, allergic reaction does not subside after eliminating its } \\
\text { contact with the skin. Contact eczema is associated with individual hypersensitivity to low-mo- } \\
\text { lecular compounds, e.g. chromium, nickel, cobalt, dyes, fragrance synthetics, aromatic oils, pre- } \\
\text { servatives [12]. }\end{array}$ \\
\hline
\end{tabular}

1). An important factor affecting the development of allergy is the place of application of a particular cosmetic. The skin in different body parts is more or less sensitive to external factors. Generally, the face skin is more sensitive than the remaining body parts. The most sensitive places are eyelids, followed by forearms and natural occlusion areas, e.g. inguinal folds. The least sensitive places are hands and hairy head skin. Due to large numbers of hair follicles, the allergenic substance permeates without forming the proper allergen at the site of contact with the skin. For this reason, symptoms of hair dye allergy are not erythema occurring on the head
The development of allergic reaction depends on the time a particular cosmetic stays on the skin. There are preparations, which stay on the skin for several hours (creams, balsams, lipsticks) and often cause skin lesions and cosmetics of short time of application, which after rinsing stay on the skin in trace amounts (shampoos, shower gels) [20].

\section{Allergenic action of fragrance substances}

Fragrance substances are the products of complex processes of biosynthesis in many plants. Studies have shown that fragrance substances are 
the most common cause of allergic reactions occurring during their use, although they are only a minimum additive [22].

Fragrance preparations include:

the basic ingredient giving fragrance, e.g. floral, fruity, spicy, musky, resinous,

substances enhancing fragrance or changing its tone,

stabilising ingredients (fixing the fragrance- fixatives),

solvents [23].

Synthetic fragrances are the most common cause of allergies to cosmetics [16]; benzoic acid, cinnamic alcohol, cinnamic aldehyde and geraniol are particularly dangerous [12]. In the last decade, balsam of Peru was a marker for allergy to fragrance substances [24]. At present, the number of allergies to this ingredient is decreasingly low $[25,10]$.

Therefore, the perfume mixture (PM) was designed for diagnostic purposes. PM contains 8 compounds, which induce allergies most frequently and cross-react with the remaining perfume ingredients. Patch tests with these compounds were performed. According to decreasing allergic activity, oakmoss absolute resulted in the highest number of positive results, followed by isoeugenol, hydroxycitronellal, geraniol, alpha-amyl cinnamic alcohol as well as eugenol, cinnamic and hydroxycitronellal aldehyde, cinnamic alcohol [26, 27]. Oakmoss absolute is a mixture of several compounds, including antranol and chlorantranol, which have the strongest allergenic properties [26a]. It is believed that the above substances, as well as Lyral (HICC), should not be used in cosmetics.

Essential oils are the main ingredient of fragrance compositions [28]. They are the products of complex processes of biosynthesis in many plants and mixtures of various chemical compounds, both liquid and solid ones dissolved in them [29]. The characteristic fragrance of essential oils results is associated with their multi-component nature. Alcohols, aldehydes, ketones, ethers, esters and others give them aroma. Their structures were determined and described in numerous publications. Thanks to advances in chemistry, some components of essential oils are increasingly produced synthetically [30].

The mixtures contain many components, including one main component, e.g. in mint oil- menthol, in chamomile oil- chamazulene [31].

Cosmetics containing chemical compounds of various composition and biological activity exert adverse effects on the human body, mainly of irritating and allergenic nature, causing various eczemas, oedemas, etc. [32,33]. During improper or prolonged storage, essential oils are exposed to significant destructive chemical processes (e.g. oxidation, polymerization), which by altering their characteristics disqualify their use, especially in cosmetology [29].

The following oils commonly cause allergic reactions: mint, thyme, citronella, cinnamon, pimento, pigweed, citric and mellisa oils. Noteworthy, some essential oils are phototoxic, i.e. increase the skin sensitivity to sun rays; the strongest effects of such nature are exerted by bergamot oil, followed by lime, sour orange, lemon and grapefruit oils. When using the above oils on unprotected skin parts, great caution should be exercised before exposure to sun or solarium tanning; otherwise, burns or uneven skin pigmentation can occur. In the summer time, cosmetic preparations and perfumes containing the above-mentioned natural substances should also be used cautiously. It is worth stressing that essential oils are characterized by high biological activity and many of them alleviate skin inflammations, e.g. chamomile, almond or rose oil. However, it should be remembered that skin sensitivity is an individual feature. People with fair complexion are more sensitive and can have problems using the preparations, which contain essential oils generally considered as safe. $[19,29]$.

To use essential oils in cosmetics, an international seal of approval is required, which confirms only the lack of evident toxicity and adverse effects [34].

Essential oils act mainly via the airway and skin. Rubbed into the skin, they reach the circulatory and lymphatic systems as well as nerve endings. Inhaled with oxygen through the lungs, they penetrate the circulatory system. Essential oils are used for baths, compresses, to treat respiratory, rheumatic, skin diseases and neurotic predispositions [22]. Moreover, they are capable of fighting infections without causing side effects and resistance of microorganisms. The most beneficial of such oils are tea tree, lavender, rosemary and lemon oils.

Both in classic aromatherapeutic procedures and in other preparations (liquids, ointments, creams), essential oils are used for all infections of the skin, genital organs, airways and many external infections. They are effective in acne, psoriasis, eczemas, mycoses, herpes viruses, influenza [35]. 
The use of essential oils for production of skincare cosmetics is of extreme importance, including the head skin, where, besides typical aroma sensations, the defined biological activity is crucial. Their application in cosmetics regards prevention and maintenance of skin physiological state [18].

However, frequent contact with fragrance substances also causes allergies, which predominantly regards workers of the cosmetic, domestic chemistry, and food industries, production of para-pharmaceuticals and sweets, bakers, gastronomy employees, hairdressers and medical personnel. The incidence of allergies to fragrance agents increases. Of $179 \mathrm{pa}-$ tients with hypersensitivity to fragrance substances, $42 \%$ are health care workers. The sources of allergy in them are disinfectants and skin-cleaning preparations with fragrance additives. Allergy to fragrance substances increases the risk of hypersensitivity to low-molecular chemical compounds present in the environment, especially to aldehydes [9].

\section{Allergenic and irritating action of preservatives}

Preservatives are used in food and cosmetic industry. They are organic and inorganic substances of bactericidal and bacteriostatic action [36]. They are to preserve good quality of cosmetics for a long time as they reduce the speed of or completely inhibit adverse changes, mainly microbiological, which spoil cosmetics or worsen their quality. Their action in cosmetics is to keep cosmetic products free of impurities during production, packaging as well as the entire time of their use, which is especially important in preparations designed for children, to which eyes or oral cavity is exposed [37]. Moreover, preservatives prevent the formation of metabolic products of micro-organisms, which can cause irritation of the skin and mucous membranes [38]. Due to their places of application (skin, mucosal regions), cosmetics contaminated with micro-organisms can constitute the health risk for users [39]. Although the number of known compounds of antimicrobial activity is high, only some of them are used in cosmetic products. This results mainly from the requirement stating that the presence of such substances in the preparation should not cause irritations or impair physiological balance of microflora saprophytically residing on the skin surface. The emulsive protective layer covering the skin surface contains saprophytes, which protect against the invasion of pathogenic micro-organisms [38]. Besides dyes and fragran- ce substances, preservatives are one of the most controversial cosmetic materials as they cause the most frequent allergies in users [37]. Table 2 presents allergenic effects of some preservatives.

Table 2. Allergenic effects of preservatives

\begin{tabular}{|c|c|}
\hline Preservatives & Possible allergic effect \\
\hline Dibromodicyanobutane & $\begin{array}{l}\text { A significant increase in allergic } \\
\text { reactions to this substance was } \\
\text { observed in recent years [40] }\end{array}$ \\
\hline Paraben esters & $\begin{array}{l}\text { They cause allergy particularly } \\
\text { when the cosmetic is used on } \\
\text { the skin with eczematous lesions } \\
\text { [1] }\end{array}$ \\
\hline Propylene glycol & Irritation or contact allergy [41] \\
\hline Urea derivatives & $\begin{array}{l}\text { Contact urticaria or allergic } \\
\text { dermatitis [1] }\end{array}$ \\
\hline Phenols & $\begin{array}{l}\text { Irritating for the mucosa and } \\
\text { skin. More concentrated phenol } \\
\text { solutions can cause necrosis of } \\
\text { the skin and deeper tissues[38] }\end{array}$ \\
\hline $\begin{array}{l}\text { Aseptines (methyl, } \\
\text { silyl and propyl ester of } \\
\text { p-hydroxybenzoic acid) }\end{array}$ & $\begin{array}{l}\text { Weak allergens. A high propor- } \\
\text { tion of allergies results from } \\
\text { their extremely frequent use of } \\
\text { use of high concentrations[11] }\end{array}$ \\
\hline Formalin Formalin & $\begin{array}{l}\text { In the past, it was very popular } \\
\text { yet was found to be one of the } \\
\text { strongest allergens. It has been } \\
\text { withdrawn from cosmetic pro- } \\
\text { ducts and replaced with the } \\
\text { preparations releasing formal- } \\
\text { dehyde. The substances induce } \\
\text { eczema only in strongly allergic } \\
\text { individuals [12] }\end{array}$ \\
\hline $\begin{array}{l}\text { Isothiazolones (Kathon } \\
\text { CG) }\end{array}$ & $\begin{array}{l}\text { Allergenic action regards the } \\
\text { use of high concentrations. } \\
\text { Kathon CG is mainly used in } \\
\text { shampoos. [3] }\end{array}$ \\
\hline Formic acid & $\begin{array}{l}\text { Irritating properties, causes skin } \\
\text { congestion, which is also used } \\
\text { in some cosmetic preparations } \\
{[38]}\end{array}$ \\
\hline Salicylic acid & $\begin{array}{l}\text { It should not be an ingredient of } \\
\text { preparations for children below } \\
\text { the age of } 3 \text { years [39] }\end{array}$ \\
\hline Ethanol & $\begin{array}{l}\text { Irritating effects on the skin are } \\
\text { observed after the use of high } \\
\text { concentrations of ethanol solu- } \\
\text { tions (above } 30 \% \text { ) [21] }\end{array}$ \\
\hline
\end{tabular}

For the safety of individuals, preservatives in food products and in cosmetics should prevent microbiological impurities. However, in cosmetics, their amounts should be minimum and they should have the following properties - broad-spectrum of 
action against micro-organisms, combined effects with other cosmetic ingredients, good toxicological profile, and contribute to a reduction in production costs [17]. Moreover, a good preservative should be well compatible physiologically, non-toxic, non-irritating, non-allergic, without taste, smell or colour, resistant to light, oxygen, elevated temperature [37].

There are norms defining the concentration of preservatives, mainly regarding substances, which can be used in cosmetic products. The norms are to minimize the risk of irritations associated with the use of cosmetics.

The effectiveness and possible development of skin irritation depend of the type of preservatives, whether they are synthetic, natural or similar to natural substances [40]. The use of too high concentrations of preservatives to obtain preparations of desirable purity can induce skin irritation or allergy in users [41]. The individual countries prepared lists of cosmetic preservatives approved for use together with their recommended concentrations [37]. Ethyl alcohol can be an alternative to preservatives. It is indicated for care of oily skin due to its dehydrating effects [40]. The use of preservatives can be partially replaced with pasteurisation- warming to $80^{\circ} \mathrm{C}$, which does not however guarantee the protection against infections during use. The concept of using natural preservatives, particularly various essential oils, is difficult to apply due to allergenic properties of many of them, e.g. chamomile oil has bactericidal effects but is also a potent allergen [16].

\section{Allergenic effects of dyes}

The ingredient of cosmetic dues most commonly causing allergic reactions is p-phenylenediamine (PPD), popularly called " fake henna". It induces symptoms of allergic contact eczema and strong urticarial reaction $[42,43]$. It causes so severe reactions resulting in retina damage that many countries banned its use, recommending the use of paratoluenediamine of weaker allergenic action. The incidence of PPD allergies has recently decreased thanks to the use of substantially more pure preparations (additives were highly allergic) and better rinsing off the excess dye by applying more effective shampoos. The European Union permits only black PPD hair dye; nevertheless, additives can be found in almost all hair dyes $[2,42,44]$. Clinical symptoms of PPD allergy have also decre- ased recently; head skin pruritus accompanied by erythema is still observed. At present, PPD allergic tests can be prophylactically conducted in clients who due hair [45].

Eosin is a dye used in cosmetics in Asian and Arabia countries, which was withdrawn from European countries due to allergenic properties. The other allergic dyes are toluidine red, lead oxide and lithium red calcium salts.

\section{Allergenic effects of artificial nails}

Few literature data demonstrate allergic symptoms induced by acrylic nails. Acrylic nails cause contact eczema on the hands, cheeks, chin and nose tip. The other symptoms involve cases of onycholysis, onychodystrophy, paresthesia and permanent nail damage $[3,45]$. The components of polymerization - methacrylic acid and its derivative butyl methacrylate are absorbed through the airway, skin and gastrointestinal tract inducing allergy symptoms. Methacrylic acid can also cause lacrimation, rhinitis, cough, chest and abdominal pains [46]. According to animal studies, butyl methacrylate induces systemic effects, such as changes in arterial pressure and heart action, changes in the liver and cerebral cortex; Moreover, it has embryotoxic and teratogenic effects [47]. The literature reports confirming adverse side effects of gel nails and tips are sparse.

\section{Other ingredients of cosmetics that cause aller- gy symptoms}

The other ingredients of cosmetics inducing allergies are emollients, nourishing and moisturising agents, and media.

Emollients are cosmetic agents that soften and soothe the epidermis. They tone, relax and increase hydration of the keratocyte layer by forming the layer on the epithelial surface, which hinders the escape of water. The emollient properties are found in esters of fatty acids, esters of fatty alcohols and quaternary ammonium salts [38]. An example allergic factor is synthetic lipophilic diester of caprylic alcohol and malonic acid, used for over 10 years in skincare cosmetics and as a sunscreen [2].

Cosmetics contain chemical compounds of various composition and biological activity; therefore, during the use of cosmetics, particularly for a longer time, symptoms of adverse side effects can often develop. The symptoms predominantly regard irritating and allergising effects 
- various eczemas, oedemas, etc.[32]. Apart from preservatives and essential oils, allergic effects can be exerted by phenols, thioglycolates, dyes, acids, hydroxides (Table 3). The incidence of allergies to a particular compound is markedly dependent on its irritating and allergising properties. Such properties of cosmetic materials are usually moderate or weak. The commonly known ingredients of strong irritating effects are successively eliminated or their use substantially limited [34].

Moreover, media used in cosmetics can also cause of allergies. Such media include nourishing agents (lanolin, eucerin) and moisturising agents (propylene glycol) [12].

Table 3. Allergenic cosmetic ingredients
Considering increasing numbers of hypersensitive individuals, in whom factors of allergenic effects can cause health- or life-threatening reactions, some warning measures should be used, i.e. special labelling of chemical compounds characterised by allergising properties [7]. Therefore, lists of approved cosmetic preservatives with recommended concentrations have been prepared in individual countries [34]. Moreover, lists of banned materials are issued, e.g. table 4 presents the list of prohibited essential oils. Furthermore, substances considered carcinogenic, mutagenic and those affecting reproduction have been banned.

\begin{tabular}{|c|c|}
\hline Ingredient & Occurrence and potential allergenicity \\
\hline Resorcine, sulphur, phenol & Preparations of exfoliating and anti-seborhhoeic action \\
\hline Triglycans & Preparations for cold perm; can cause skin irritation or even hair loss [32] \\
\hline Dyes & In lipsticksmascara, hair dyes and hair care lotions [32] \\
\hline Sodium hydrosulphide, alkaline compounds & Agents for per, manent perm [32] \\
\hline Polyester resins, metha-crylates, nitrocellulose & They create a membrane over the nail surface [18] \\
\hline Kalaphonia & $\begin{array}{l}\text { Ingredient of mascara, eye shadows and rouge responsible for eczema or urticaria } \\
\text { [12] }\end{array}$ \\
\hline Ethanol & Perfumes, eau cologne, toilet eau [49] \\
\hline Salicylic acid & Lotions for face skin care, deodorants [32] \\
\hline Sulphate oxyethylene products & Corn preparations [32] \\
\hline Boron compounds and soaps, sulfosuccinates & Shampoos [32] \\
\hline Silver nitrate, amine hydroxide & To dye gray hair [32] \\
\hline Honey, pollen, propolis & Fund in numerous cosmetics [18] \\
\hline $\begin{array}{l}\text { Urea hydroxide, nitric and amine aromatic compo- } \\
\text { unds, resorcine }\end{array}$ & Cosmetics to dye hair [32] \\
\hline Tweed 80 & $\begin{array}{l}\text { Used as a substance facilitating permeation of active components through the } \\
\text { epithelial horny layer. Allergy can be induced by the compound itself and pro- } \\
\text { ducts formed during oxidation of this compound in the presence of air (formal- } \\
\text { dehyde, acetaldehyde) [12] }\end{array}$ \\
\hline Vaseline, paraffin oil, paraffin, vaseline, lanolin & Balsams, creams- very often cause irritations and allergies [18] \\
\hline Superficially-active anion compounds & $\begin{array}{l}\text { Soaps, shampoos - damage the protective skin layer, which reduces the } \\
\text { resistance to irritating effects of external factors [19]. }\end{array}$ \\
\hline
\end{tabular}

\section{Legal aspects regarding safety of cosmetics}

On May 12 2002, the Act of March 2001 on cosmetics took effect, which determines requirements concerning composition, labelling and turnover of cosmetics. According to this Act, a cosmetic is any substance designed for external contact with the human body, i.e. the skin, hair, lips, nails, external genital organs, teeth and oral mucosa, whose major goal is to maintain their cleanness, provide care and protection, perfuming or beautifying [5].
Table 4. The list of essential oils prohibited for direct skin use [28]

\begin{tabular}{|l|l|l|}
\hline No. & Essential oil & Toxic ingredients \\
\hline \multirow{4}{*}{} & Cinnamomum Cassia Oil & cinnamyl aldehyde \\
\cline { 2 - 3 } & Oregano oil & Tirol, carvacrol \\
\cline { 2 - 3 } & Satureja Montana Oil & Carvacrol, tirol \\
\cline { 2 - 3 } & Sasafras oil & Safyral \\
\cline { 2 - 3 } & Chenopodium ambrosioides oil & Ascaridole \\
\hline
\end{tabular}


In Poland, such approved substances, which can be used only in the defined amounts, ranges and conditions, are included in the directives of the Minister of Health to the Act on cosmetics. [48].

The fourth amendment to the Cosmetic Directive 78/768/EEC, regarding novelisation of the Act on cosmetics of March 30th 2001, includes 26 allergens, presented in the table. Their presence has to be marked on cosmetic packages, when concentrations of these substances exceed $0.01 \%$ in rinsed-off products and $0.001 \%$ in non-rinsed-off cosmetics [8].

Table 5. The list of 26 potential allergens [8]

\begin{tabular}{|l|l|}
\hline No. & Substance \\
\hline \multirow{4}{*}{} & Amyl cinnamal \\
\cline { 2 - 3 } & Benzyl alcohol \\
\hline & Cinnamyl alcohol \\
\cline { 2 - 3 } & Citral \\
\cline { 2 - 3 } & Eugenol \\
\hline Hydroxycitronellal \\
\hline Isoeugenol \\
\hline Amyl cinnamyl alcohol \\
\hline & Benzyl salicylate \\
\hline Cinnamal \\
\hline & Coumarin \\
\hline Geraniol \\
\cline { 2 - 3 } & Methyl 2-octynoate \\
\hline Anise alcohol \\
\hline & Benzyl cinnamate \\
\hline Farnesol \\
\hline Butylphenyl methylpropional \\
\hline Linalool \\
\hline Benzyl benzoate \\
\hline Citronellol \\
\hline Hexyl cinnamal \\
\hline Limonene \\
\hline Hydroksyisohexyl 3-cyclohexene carboxaldehyde \\
\hline Alpha-isomethyl ionone \\
\hline Evernia furfuracea extract \\
\hline Evernia prunastri extract \\
\hline
\end{tabular}

Producers of cosmetics should demand from their suppliers to provide information on the content of the above-mentioned potential allergens in fragrance substances, aromas, plant extract, etc. Moreover, the total amount of a particular allergen should be determined in the product and the results should be compared with requirements. If necessary, contents should be placed on packages [8].
Furthermore, cosmetics whose ingredients or their combinations were tested on animals are banned. Producers can inform that the cosmetic was not tested on animals only when both producers and suppliers have not performed or ordered such tests of the cosmetic, its prototype nor any ingredients and when the cosmetic does not contain ingredients tested on animals by other producers searching for new cosmetics [6].

According to standards of the European Union, cosmetics should be characterized by 3 year-stability; when the expiration date is shorter, a special annotation should be provided on packages [16], preceded by the expression "Best before'. The stability should be defined in detail, month and year; conditions of its use should be specified, if need be [5]. For cosmetic products of stability longer than 30 months, the expiring date does not have to be given; however, it is obligatory to define the time the cosmetics can be used after opening without possible adverse health effects. Producers of cosmetics make this decision based on:

microbiological examinations

analytic data concerning cosmetic composition, type of packaging,

habits and ways of using cosmetics by consumers [8].

According to the Article 11, producers are obliged to keep and make available the data on:

quantitative and qualitative composition of cosmetics

physicochemical and microbiological specification of ingredients regarding chemical and microbiological purity of the cosmetic,

methods of production consistent with good manufacturing practice,

evaluation of effects of cosmetics on health safety, together with general characteristics of ingredients as for their toxicity, chemical composition, etc, as well as the name and address of those responsible for evaluations,

clear data about adverse effects on health resulting from the use of cosmetics

documentation of study results regarding adverse effects, if they occur [5].

\section{References:}

1. Maski S. Podrażnienia i alergie jako reakcje na kosmetyki. Wiad. Poi. Tow. Kosm. 2003; 6(11): 17-19.

2. Chan I, Wakelin SH. Allergic contact dermatitis from dioctyl maleate in a moisturizer. Cont. Dermat. 2006; 55: 250-254. 
3. Isaksson M, Siemund I, Bruze M. Allergic contact dermatitis from ethylcyanoacrylate in an office worker with artifical nails led to months of sick leave. Cont. Dermat. 2007; 57: 346-347.

4. Żukiewicz-Sobczak W, Adamczuk P, Wróblewska P, Zwoliński J, Chmielewska-Badora J, Krasowska EJ, et al. Allergy to selected cosmetic ingredients. Postep. Derm. Alergol. 2013; 30(5): 307-310.

5. Ustawa o kosmetykach z dnia 30 marca 2011. Dz. U., 2011, Nr. 42, poz. 473.

6. Ustawa o kosmetykach z dnia 27 sierpnia 2004. Dz. U., 2004, Nr 213, poz. 2158 z późn. zm.

7. Puchalska H. Klasyfikacja i oznakowanie niebezpiecznych substancji chemicznych. Bezp. Pracy. 2002; 3: 4-16.

8. Tańczyk T. Poprawka do 7 Dyrektywy Kosmetycznej 78/768/EEC, Arom. 2004; 37(3): 10, 27-29.

9.Pałczyński C. Alergia zawodowa u pracowników służby zdrowia. Łódź: Instytut Medycyny Pracy; 2000.

10. Wojciechowska M, Gocki J, Bartuzi Z. Występowanie objawów ubocznych, nadwrażliwości i alergii na wybrane składniki kosmetyków oraz chrom i nikiel wśród studentek kosmetologii. Alerg. Ast. Immunol. 2007; 12(2): 87-91.

11. Kacalak-Rzepka A, Bielecka-Grzela S, RóżewickaCzabańska M, Maleszka R, Klimowicz A. Nadwrażliwość kontaktowa na wybrane składniki kosmetyków oraz inne alergeny wśród kosmetyczek i studentek kosmetologii. Post. Dermatol. Alergol. 2010; (27)5: 400-405.

12. Kamieńska A, Orszułak - Michalak D, Złotowska Ł.Kosmetyki czy zawsze bezpieczne. Pol. J.Cosmetol. 2005; 1: 2-5.

13. Davies RJ. Poradnik medyczny. Warszawa: Wiedza i Życie; 2001.

14. Niggemann B, Wahn U. Alergia u dzieci. Warszawa: PZWL; 2001.

15. Romański B. Alergia i choroby alergiczne. Warszawa: PZWL; 1999.

16. Lange - Ernst ME. Kosmetyki naturalne. Warszawa: Świat Książki; 1995.

17. Sabourin JR. Evaluation of preservatives for cosmetics. Drug Cosm. Ind.. 1990; 12: 20-25.

17 a. Sabourin JR. Selecting preservatives for creams and lotions. Cosm. Toilet. 1986; 11: 30-36.

18. Sikora M. Alergeny w kosmetykach cz. 2. Bez recepty. 2004; 10: 15-18.

19. Lin A, Góra J. Olejki z różnych gatunków pomarańczy. Arom. 1997; 3, 3 (9): 5-8.

20. Sikora M. Kosmetyki dla alergików. Bez recepty. 2003; 5: 15-19.

21. Polo KF. A short testbook of technology. Augsburg: 1998.

22. Książkiewicz T. Ziołolecznictwo Ojców Bonifratrów dla kobiet. Warszawa: Wyd. Adam; 1996.

23. Marzec A. Chemia kosmetyków. Toruń: Wyd. Organizatora; 2001.
24. Temesvan E, Nemeth I, Balo-Banga MJ. et.al. Multicentre study of fragrance allergy in Hungary. Cont. Dermat. 2004; 46: 325-330.

25. Hans-Jurgen S. Skin diseases in workers at a perfume factory. Cont. Dermat. 2006; 55: 81-83.

26. Johansen J, Menne T. The fragrance mix and ist constituents: a 14-year material. Contact Dermatitis. 1995; 32: 15-23.

26 a.Johansen JD, Andersen KE, Svedman C. et al. Chloroatranol, an extremely potent allergen hidden in perfumes, a doses-response elicitation study. Cont. Dermat. 2003; 49: 181-184.

27. Hendriks S, Ginkel C. Evaluation at the fragrance mix in the European Standard Series. Contract Dermatitis. 2000; 41: 161-164.

28. Góra J. Toksyczne składniki olejków eterycznych. Arom. 2001; 3(25): 7, 28-32.

29. Wójcik P. Olejki eteryczne w kosmetyce. Wiad. Ziel. 1999; 7/8: 24-31.

30. Gąsior M, Czaja V. Zastosowanie oleju rycynowego w kosmetykach i

farmacji. Chem. Spoż. i Biotech., Zesz. Nauk. Łódź: Politechnika Łódzka; 2002.

31. Kwaśniewska J, Mikołajczyk K. Zbieramy zioła. Warszawa: Wyd. Akcydensowe; 1996.

32. Seńczuk JR. Toksykologia - podręcznik dla studentów farmacji. Warszawa: PZWL; 1994.

33. Aberer W. Contact allergy and medicinal herbs. J Dtsch Dermatol Ges. 2008; 6(1): 15-24.

34. Sikora M. Alergeny w kosmetykach cz. 1. Bez recepty. 2004; 9: 12-14.

35. Brud W, Konopacka-Brud J. Olejki eteryczne jako substancje czynne w

kosmetykach. Wiad. Ziel. 1998; 7/8: 8-10.

36. Glinka R. Nowe idee w recepturze kosmetycznej. Łódź: AM; 1998.

37. Sikora M. Konserwanty w kosmetyce. Chem. Rev. 2005; 2: 26-35.

38. Malinka W. Emolienty. Zarys chemii kosmetycznej. Wrocław: Volumed; 1999. p. 213-234.

39. Joswig S, Lolo - Iwanowska A. Interakcje konserwantów ze składnikami

kosmetyków. Wiad. Poi. Tow. Kosm. 2002; 5,1(5): 17-18.

40. Lautenschlaeger H. Konserwanty w kosmetykach. Kosm. Kosmetol. 2005; 64: 3, 18-20.

41. Brud W, Chrząszcz M. Olejki eteryczne jako naturalne konserwanty.

Arom. 1998; 4,4(14): 20-26.

42.Bimie AJ, English JS. Immediate hypersensivity to pharaphenylenediamine. Cont. Dermat. 2007; 56: 240-244.

43. White JML, Basketter DA, Pease C, et al. Intermittent exposure to low-contraction paraphenylenediamine con be equivalent to single, higer- dose exposure. Cont. Dermat. 2007; 56: 262-265

44. Kieć-Świerczyńska M. Alergeny kontaktowe. Alergia kontaktowa. Łódź: Medion; 2005. p. 67-75. 
45. Rich P. Nail cosmetics and carmouflaging techniques. Dermatol. Ther. 2001; 14: 228-236.

46. www2.cyf.gov.pl

47. www.ciop.pl

48. Czerczak S. Klasyfikacja chemicznych czynników rakotwórczych. Bezp.

Pracy. 2004; 1: 9-14.

49. Gruening R. As much as necessary, as little as possible. Cosm. Toilet. 1998; 113: 4, 61-66.

\section{Correspondence address:}

Prof. Jerzy Truchliński PhD

Vincent Pol University in Lublin,

ul. Choiny 2

20-816 Lublin, Poland 